\title{
Active warming of saline or blood is ineffective when standard infusion tubing is used: an experi- mental study
}

\author{
[Le réchauffement actif d'une solution salée ou de sang est inefficace quand on \\ utilise une tubulure à perfusion standard]
}

Bruno Bissonnette MD FRCPC, Olivier Paut MD

Purpose: To determine the effect of infusion rate, tubing length and fluid composition on the temperature of the infusate reaching the distal end of an infusion tubing with and without active fluid warming.

Methods: Warmed normal saline (W-NS) and packed red blood cells (W-PRBC), were infused with a fluid warmer through a modified infusion set. The fluids were delivered at eight infusion rates from 50 to $999 \mathrm{~mL} \cdot \mathrm{hr}^{-1}$. The infusate temperature was monitored at 20 $\mathrm{cm}$ intervals on the iv tubing. The same temperature monitoring protocol was applied to PRBC without warmer (NoW-PRBC).

Results: In W-NS and W-PRBC groups, there was a decrease in the infusate temperature, at each flow rate, from the drip chamber to the distal end of tubing $(P<0.00 \mathrm{I})$. In NoW-PRBC group, there was a rapid increase in the infusate temperature from the bag to the drip chamber $(P<0.001)$. Thereafter, there was no change in temperature, except at the $999 \mathrm{~mL} \cdot \mathrm{hr}^{-1}$ infusion rate, where a slight increase in the infusate temperature throughout the tubing was shown. In W-NS and W-PRBC groups increasing the flow rate produced a significant increase in the infusate temperature, at each measurement point $(P<0.00 \mathrm{I})$. In the NoW-PRBC group, increasing the flow rate did not alter the infusate temperature. The fluid composition did not influence the infusate temperature.

Conclusion: There is an important heat exchange within the tubing, which is aggravated at low flow rates. At infusion rates appropriate for pediatric anesthesia the clinical and economic value of fluid warming without the use of heated extension tubing is questionable.

Objectif: Déterminer l'effet de la vitesse de perfusion, de la longueur de la tubulure et de la composition du liquide sur la température de la solution intraveineuse à la partie distale de la tubulure, le liquide étant soumis ou non à un réchauffement actif.
Méthode : Une solution salée (SS-R) et un concentré de globules rouges réchauffés (CGR-R) ont été perfusés avec un ensemble à perfusion modifié comprenant un réchauffeur de liquide. Les liquides ont été administrés selon huit vitesses de perfusion, de 50 à $999 \mathrm{~mL} \cdot \mathrm{h}^{-1}$. La température du soluté a été mesurée à des intervalles de $20 \mathrm{~cm}$ sur la tubulure iv. Le même protocole de surveillance de la température a été appliqué au CGR non réchauffé (CGR-NonR).

Résultats : Dans les groupes SS-R et CGR-R, la température du liquide perfusé a baissé pour toutes les vitesses de perfusion, entre la chambre compte-gouttes et la partie distale de la tubulure $(P<$ $0,001)$. Dans le groupe CGR-NonR, elle a augmenté rapidement, entre le sac et la chambre compte-gouttes $(P<0,001)$. Par la suite, il n'y a pas eu de changement de température, sauf à $999 \mathrm{~mL} \cdot h^{-1}$, où on a noté une légère hausse au travers de la tubulure. Dans les groupes SS-R et CGR-R, l'augmentation de la vitesse de perfusion a produit une augmentation significative de la température de la solution intraveineuse, à chaque point de mesure $(P<0,001)$. Dans le groupe CGR-NonR, l'augmentation de la vitesse d'écoulement n'a pas modifié la température du liquide. La composition de la solution n'a pas changé la température.

Conclusion : Il se produit un important échange de chaleur à l'intérieur de la tubulure, échange qui est augmenté aux basses vitesses de perfusion. À des vitesses de perfusion appropriées à l'anesthésie pédiatrique, la valeur clinique et économique du réchauffement du liquide sans l'utilisation d'une extension chauffante est discutable.

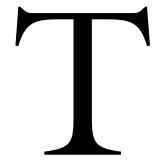

$\mathrm{H} \mathrm{E}$ importance of maintaining intraoperative normothermia during pediatric anesthesia is well established. ${ }^{1}$ While hypothermia may convey some benefits such as cerebral protection, ${ }^{2,3}$ most often those are

From the Department of Anaesthesia, The Hospital for Sick Children and University of Toronto, Toronto, Ontario, Canada. Address correspondence to: Dr. Bruno Bissonnette, Department of Anaesthesia, The Hospital for Sick Children, 555 University Avenue, Toronto, Ontario M5G 1X8, Canada. Phone: 416-813-7455; Fax: 416-813-7543; E-mail: bruno@anaes.sickkids.on.ca Accepted for publication July 3, 2001. Revision accepted September 26, 2001. 
outweighed by numerous drawbacks. There is now convincing evidence that a typical amount of intraoperative hypothermia, of the order of $2^{\circ} \mathrm{C}$, predisposes to complications and alters patient outcome. ${ }^{4}$ Perioperative hypothermia was shown to prolong recovery, ${ }^{5}$ to increase oxygen demands in the postoperative period, ${ }^{6}$ to increase bleeding, ${ }^{7,8}$ and to decrease surgical wound healing. ${ }^{9}$

The role of fluid warming as an adjunct to prevent hypothermia during anesthesia has received significant coverage in the anesthesia literature. ${ }^{1}$ Fluid warmers are designed to raise the temperature of the solution flowing through a coil to the stable temperature of the heater. This is defined as the thermal load. ${ }^{10}$ The literature to date has focused on the ability for warmers to rapidly warm large quantities of fluid and contributed to the optimal design of such devices. ${ }^{10,11}$ Few investigations have studied the consequences of flowing warmed solutions throughout plastic delivery tubing on fluid thermal loss. ${ }^{12}$ Faries et al., using a standard iv tubing of $105 \mathrm{~cm}$ in length and normal saline (NS) warmed at $37^{\circ} \mathrm{C}$ within a fluid warmer, demonstrated that heat loss during transit of the infusate was significant. ${ }^{12}$ In pediatric anesthesia where flow rates are relatively low and volumes administered most often small, this consideration becomes of greater importance. ${ }^{3}$

This study was designed to determine the effect of various infusion rates, length of the extension tubing and fluid composition on the temperature of the infusate warmed by a fluid warmer and subsequently flowing to the distal end of the administration system.

\section{Methods}

The model consisted of modified administration sets and extension tubing. Modifications were made by placing temperature sensors (Mon-A-Therm, Inc., Montréal, Quebec, Canada) at $20-\mathrm{cm}$ intervals through the tubing wall into the infusion tubing lumen. The temperature sensors had a precision of $0.01^{\circ} \mathrm{C}$ and a time constant of $0.08 \mathrm{sec}$. Small needle holes were created to allow passage of the thermocouples and were subsequently sealed with epoxy cement (cyanoacrylate $8 \%$ solution).

In the first group (W-NS group), NS was warmed with a Fenwal blood warmer (model BW-5; Travenol laboratories, Inc., Deerfield, IL, USA). The blood warmer temperature was set at $36.4-36.6^{\circ} \mathrm{C}$. A modified Fenwall disposable set (Baxter Healthcare Corporation, Fenwal division; Deerfield, IL, USA) and two modified extension sets (MED-RX, Benlan Inc., Oakville, Ontario, Canada) were connected in series using a threeway stopcock (Medex, Inc.; Hilliard, OH, USA).
The total length of tubing after the drip was $240 \mathrm{~cm}$.

In the second group, (W-PRBC group), human outdated packed red blood cells (PRBC) diluted 1:1 with refrigerated NS were warmed and infused in the same way than in group W-NS.

In the third group, (NoW-PRBC group), PRBC at 4 to $10^{\circ} \mathrm{C}$ were delivered with a $\mathrm{Y}$ type blood set (model N 1873, Abbott, North Chicago, IL, USA) and then connected in series with the same material as previously described. Temperature probes were placed at the outflow of the PRBC bag, and then at $20-\mathrm{cm}$ intervals. The remainder of the iv tubing consisted of a three-way stopcock and an extension set for a total length of $240 \mathrm{~cm}$. The temperature of the PRBC bag was monitored and maintained constant by using a servo-controlled ice bath throughout the experiment.

In all groups, the infusate flow rate was controlled using an IVAC variable pressure volumetric pump (model no. 560 MEE; IVAC San Diego, CA, USA). The infusate was delivered at eight different flow rates $\left(50,100,150,200,250,500,750\right.$ and $\left.999 \mathrm{~mL} \cdot \mathrm{hr}^{-1}\right)$ in each group.

\section{Temperature measurements}

The temperatures were recorded when the readings had stabilized within a range of $\pm 0.2^{\circ} \mathrm{C}$, after a variable duration of infusion. This period of equilibration required between ten and 30 min depending on the infusion rate. Data were simultaneously recorded at all monitoring points every $30 \mathrm{sec}$ for ten minutes, using a computer. Temperature was monitored from the drip of the fluid warmer set, to the distal end of the infusion set $(240 \mathrm{~cm})$ at $20 \mathrm{~cm}$-intervals. Room temperature was kept constant throughout the experimental sessions.

\section{Statistical analysis}

All parametric data are expressed as mean \pm SD. Within group data were analyzed using an ANOVA and Dunnett's test for multiple comparisons with the baseline initial temperature measurement (drip chamber site). Inter groups comparison between each measurement site at each infusion rate was done with one-way ANOVA and the Tukey-Kramer test for multiple comparisons. To test the effect of the fluid composition on the infusate temperature, we compared the temperatures of W-NS with those of W-PRBC at each infusion rate using a one-way ANOVA with a Bonferroni multiple comparison test. $P<0.05$ was accepted to express statistical significance, with, as needed, Bonferroni's correction. 


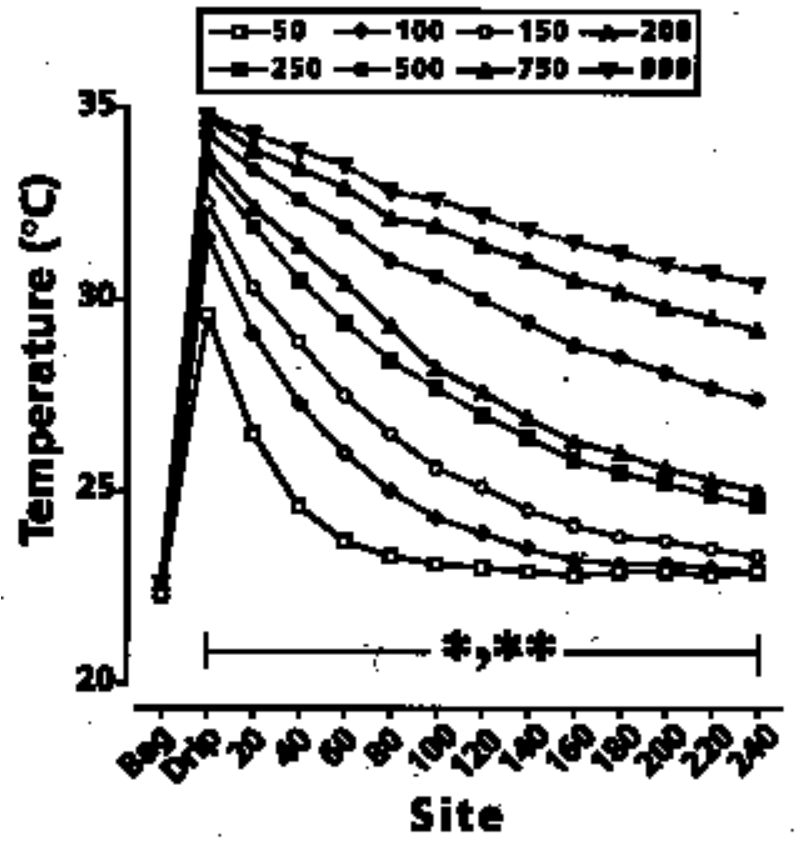

FIGURE 1 Temperature of the normal saline infusate at sequential monitoring points within the experimental circuit. The fluid warmer was inserted between the fluid bag and the drip chamber. Eight infusion rates were tested, from $50 \mathrm{~mL} \cdot \mathrm{hr}^{-1}$ to $999 \mathrm{~mL} \cdot \mathrm{hr}^{-1}$. ${ }^{\star} P<0.001$ denotes difference within groups at each infusion rate, ${ }^{* *} P<0.001$ denotes difference between groups at each measurement point.

Results

The room temperature was maintained at $22.4 \pm$ $0.2^{\circ} \mathrm{C}$ throughout the experimental session.

\section{Influence of tubing length on the infusate temperature} In W-NS group and W-PRBC group, at each rate of infusion, there was a significant decrease in the infusate temperature from the drip chamber to the distal end site $(P<0.001$ among all sites) (Figures 1 and 2). In group W-NS, there was a significant decrease between the drip chamber and the distal end temperatures, from $29.5 \pm 0.08^{\circ} \mathrm{C}$ to $22.8 \pm 0.04^{\circ} \mathrm{C}$ at $50 \mathrm{~mL} \cdot \mathrm{hr}^{-1}(P<0.001)$ and from $34.8 \pm 0.1^{\circ} \mathrm{C}$ to $30.4 \pm 0.1^{\circ} \mathrm{C}$ at $999 \mathrm{~mL} \cdot \mathrm{hr}^{-1}(P<0.001)$. In group W-PRBC, there was a significant decrease between the drip chamber and the distal end temperatures from $30.0 \pm 0.04^{\circ} \mathrm{C}$ to $22.7 \pm 0.04^{\circ} \mathrm{C}$ at $50 \mathrm{~mL} \cdot \mathrm{hr}^{-1}(P$ $<0.001)$ and from $34.7 \pm 0.1^{\circ} \mathrm{C}$ to $30.4 \pm 0.1^{\circ} \mathrm{C}$ at $999 \mathrm{~mL} \cdot \mathrm{hr}^{-1}(P<0.001)$.

In the NoW-PRBC group, there was a significant increase between the bag and the drip temperatures from $5.6 \pm 0.3^{\circ} \mathrm{C}$ to $22.4 \pm 0.02^{\circ} \mathrm{C}(P<0.0001)$ at 50

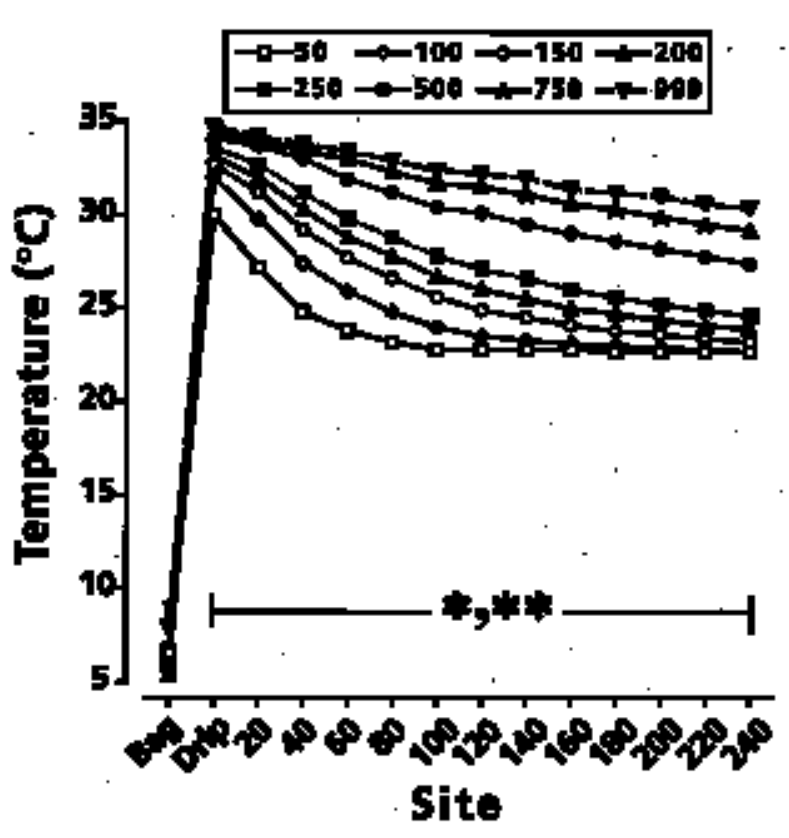

FIGURE 2 Temperature of the packed red blood cells at sequential monitoring points within tubing through the experimental circuit. The fluid warmer was put on between the fluid bag and the drip chamber. Eight infusion rates were tested, from 50 $\mathrm{mL} \cdot \mathrm{hr}^{-1}$ to $999 \mathrm{~mL} \cdot \mathrm{hr}^{-1} \cdot{ }^{*} P<0.001$ denotes difference within groups at each infusion rate, ${ }^{* *} P<0.001$ denotes difference between groups at each measurement point.

$\mathrm{mL} \cdot \mathrm{hr}^{-1}$, and from $8.0 \pm 2.2$ to $19.8 \pm 0.1^{\circ} \mathrm{C}$ at 999 $\mathrm{mL} \cdot \mathrm{hr}^{-1}(P<0.0001)$. There was no significant difference between the different temperature sites at each infusion rate, except at $999 \mathrm{~mL} \cdot \mathrm{hr}^{-1}$, where there was a slight but significant increase in the temperature from the drip chamber to the distal end tubing, from $19.8 \pm 0.1^{\circ} \mathrm{C}$ to $21.0 \pm 0.1^{\circ} \mathrm{C}(P<0.001$; Figure 3$)$.

\section{Influence of the rate of infusion on the infusate temperature}

In the W-NS group, at each measurement point, increasing the rate of infusion produced a significant increase in the infusate temperature $(P<0.001$ between all measurement points). Increasing the infusion rate from $50 \mathrm{~mL} \cdot \mathrm{hr}^{-1}$ to $999 \mathrm{~mL} \cdot \mathrm{hr}^{-1}$ produced an increase from $29.6 \pm 0.1{ }^{\circ} \mathrm{C}$ to $34.8 \pm 0.03^{\circ} \mathrm{C}$ at the drip cham ber and from $22.7 \pm 0.05^{\circ} \mathrm{C}$ to $29.9 \pm 0.1^{\circ} \mathrm{C}$ at the 240 $\mathrm{cm}$ measurement site respectively $(P<0.001$; Figure 1$)$.

In the W-PRBC group, at each measurement point, increasing the rate of infusion produced a significant increase in the infusate temperature $(P<0.001$ 


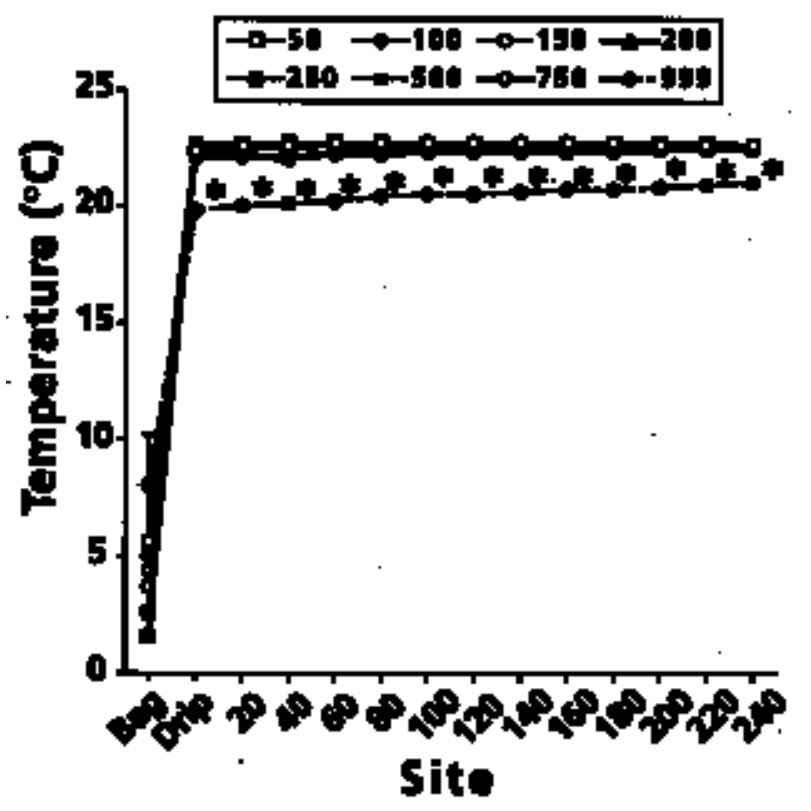

FIGURE 3 Temperature of packed red blood cells at sequential monitoring points within the experimental circuit. No fluid warmer was used. Eight infusion rates were tested, from 50 $\mathrm{mL} \cdot \mathrm{hr}^{-1}$ to $999 \mathrm{~mL} \cdot \mathrm{hr}^{-1}{ }^{*} P<0.01$ between the $999 \mathrm{~mL} \cdot \mathrm{hr}^{-1}$ infusion rate and all other infusion rates.

between all measurement points, Table). Increasing the infusion rate from $50 \mathrm{~mL} \cdot \mathrm{hr}^{-1}$ to $999 \mathrm{~mL} \cdot \mathrm{hr}^{-1}$ produced an increase from $30.0 \pm 0.04^{\circ} \mathrm{C}$ to $34.7 \pm$ $0.1^{\circ} \mathrm{C}$ at the drip chamber and from $22.6 \pm 0.05^{\circ} \mathrm{C}$ to $29.7 \pm 0.2^{\circ} \mathrm{C}$ at the $240 \mathrm{~cm}$ measurement points respectively $(P<0.001$; Figure 2$)$.

In the NoW-PRBC group, increasing the rate of infusion from 50 to $750 \mathrm{~mL} \cdot \mathrm{hr}^{-1}$ produced no significant change in temperature. The temperatures measured at all sites within the tubing at a flow rate of 999 $\mathrm{mL} \cdot \mathrm{hr}^{-1}$ was significantly decreased when compared to those at different infusion rates $(P<0.001$; Figure 3$)$.

\section{Influence of fluid composition on the infusate temperature}

There was no significant difference between the temperatures of NS and PRBC delivered at different infusion rates whatever the site of temperature measurement (Table).

Discussion

In this study we have shown that the tubing length has a major influence on the temperature of fluids administered via conventional infusion sets. While both NS and PRBC were warmed with an effective device, their temperatures dropped considerably from the drip chamber to the distal end of the tubing. There was no clinically relevant difference between NS and PRBC, which demonstrated a similar decline in their temperature along the circuit. The present study has also demonstrated that PRBC administered via the same infusion set, without being warmed by a fluid warmer, had its temperature rapidly increased, close to ambient temperature. The rate of infusion played an important role in the thermal conductivity and the heat loss since the decrease in the infusate temperature augmented as the infusion rate was reduced.

These results are in accordance with previous data. In a laboratory study, Faries et al. have reported that the temperature of NS after a passage through a fluid warmer decreased within the tubing. ${ }^{2}$ They also showed that during a slow to moderate infusion, the temperature of the fluid delivered was near room temperature. Only the higher infusion rates (750 and 1,000 $\mathrm{mL} \cdot \mathrm{hr}^{-1}$ ) were associated with an appropriate infusate temperature at the end of the tubing, above $32^{\circ} \mathrm{C} . .^{12}$ Their conclusion was that, at flow rates used in the pediatric setting, benefit of using a fluid warmer is reduced by the use of customary length of iv tubing. ${ }^{12}$ Two other studies have shown that using a warming device connected to conventional $i v$ tubing, the infusate temperature decreased as a consequence of heat exchange between the fluid and the environment across the tubing. ${ }^{14,15}$ In those two studies, it was clearly demonstrated that the thermal loss was increased at the lower rates of infusion used in children. ${ }^{14,15}$ Heat exchange across the polyvinyl chloride tubing wall and the environment is explained by the thermal conductivity of the tubing. ${ }^{16}$ The increase in the temperature of PRBC observed in the present study is the result of temperature equilibration with ambient air. The nature of tubing material and its surface area influence the conductance coefficient that determines the rate of heat transfer between the infusate and the environment. Even though the conductance coefficient of plastic is relatively low $(0.25$ $\left.\mathrm{kcal} \cdot \mathrm{m}^{-1} \cdot \mathrm{hr}^{-1} \cdot{ }^{\circ} \mathrm{C}^{-1}\right)$ when compared to highly conductive material such as aluminium $\left(273 \mathrm{kcal} \cdot \mathrm{m}^{-1} \cdot \mathrm{hr}^{-1} \cdot{ }^{\circ} \mathrm{C}^{-1}\right)$, the tubing surface area and the flow rate are sufficient to explain the rapid heat exchange. ${ }^{17}$ The lack of difference between NS and PRBC profiles for heat loss demonstrated in the present study had not yet been described. Although Presson et al. studied NS and cold blood and reported a similar profile in temperature warming and cooling, no direct comparison between the two solutions was provided. ${ }^{14}$ The thermal conductivity of blood $\left(0.5 \mathrm{~W} \cdot \mathrm{m}^{-1} .{ }^{\circ} \mathrm{C}^{1}\right)$ which is similar to that of water $(0.6$ $\left.\mathrm{W} \cdot \mathrm{m}^{-1} \cdot{ }^{\circ} \mathrm{C}^{-1}\right)$, explains this finding. ${ }^{18}$ 
TABLE Influence of fluid composition on the infusate temperature $\left({ }^{\circ} \mathrm{C}\right)$ withing tubing

\begin{tabular}{|c|c|c|c|c|c|c|c|c|}
\hline \multirow[t]{2}{*}{ Site/rate } & \multicolumn{2}{|c|}{$50 \mathrm{~mL} \cdot \mathrm{hr}^{-1}$} & \multicolumn{2}{|c|}{$100 \mathrm{~mL} \cdot \mathrm{hr}^{-1}$} & \multicolumn{2}{|c|}{$500 m L \cdot h r^{-1}$} & \multicolumn{2}{|c|}{$999 m L \cdot h r^{-1}$} \\
\hline & $N S$ & $P R B C$ & $N S$ & $P R B C$ & NS & $P R B C$ & $N S$ & $P R B C$ \\
\hline Drip & $\begin{array}{l}29.6 \\
(0.08)\end{array}$ & $\begin{array}{l}30 \\
(0.04)\end{array}$ & $\begin{array}{l}31.6 \\
(0.08)\end{array}$ & $\begin{array}{l}31.9 \\
(0.07)\end{array}$ & $\begin{array}{l}34.3 \\
(0.04)\end{array}$ & $\begin{array}{l}34.1 \\
(0.09)\end{array}$ & $\begin{array}{l}34.9 \\
(0.03)\end{array}$ & $\begin{array}{l}34.7 \\
(0.1)\end{array}$ \\
\hline $80 \mathrm{~cm}$ & $\begin{array}{l}23.3 \\
(0.07)\end{array}$ & $\begin{array}{l}23.3 \\
(0.07)\end{array}$ & $\begin{array}{l}25 \\
(0.05)\end{array}$ & $\begin{array}{l}24.8 \\
(0.05)\end{array}$ & $\begin{array}{l}30 \\
(0.09)\end{array}$ & $\begin{array}{l}31.2 \\
(0.07)\end{array}$ & $\begin{array}{l}32.8 \\
(0.05)\end{array}$ & $\begin{array}{l}32.9 \\
(0.09)\end{array}$ \\
\hline $160 \mathrm{~cm}$ & $\begin{array}{l}22.8 \\
(0.1)\end{array}$ & $\begin{array}{l}22.8 \\
(0.08)\end{array}$ & $\begin{array}{l}23.2 \\
(0.1)\end{array}$ & $\begin{array}{l}23.1 \\
(0.08)\end{array}$ & $\begin{array}{l}28.8 \\
(0.09)\end{array}$ & $\begin{array}{l}28.9 \\
(0.05)\end{array}$ & $\begin{array}{l}31.4 \\
(0.07)\end{array}$ & $\begin{array}{l}31.4 \\
(0.16)\end{array}$ \\
\hline $240 \mathrm{~cm}$ & $\begin{array}{l}22.9 \\
(0.04)\end{array}$ & $\begin{array}{l}22.7 \\
(0.05)\end{array}$ & $\begin{array}{l}22.9 \\
(0.04)\end{array}$ & $\begin{array}{l}22.7 \\
(0.05)\end{array}$ & $\begin{array}{l}27.4 \\
(0.09)\end{array}$ & $\begin{array}{l}27.4 \\
(0.08)\end{array}$ & $\begin{array}{l}30.4 \\
(0.09)\end{array}$ & $\begin{array}{l}30.4 \\
(0.16)\end{array}$ \\
\hline
\end{tabular}

For simplification only four infusion rates are reported. NS=normal saline, PRBC=packed red blood cells. Values within brackets represent SD. There were no significant difference between fluids.

Warming fluid infusions is recommended during massive blood transfusion or fluid expansion in trauma and in hypothermia, ${ }^{19}$ or in pediatric anesthesia, particularly in neonates or in children sustaining large volume expansion. ${ }^{1}$ A fluid warmer represents an efficient tool for warming infusates. ${ }^{10,11,19-22,23}$ There are some discrepancies among the performances of fluid warmers, those using countercurrent technology warming blood and saline more effectively than do fluid warmers that use either dry heat or water bath technology. ${ }^{2}$ At flow rates usual in children, one can consider these differences as minimal and the fluid will be effectively warmed at the output of the warming device. However, the use of a fluid warmer will only be clinically relevant and cost effective if the temperature of the fluid at the end of the tubing is similar or close to that of the warmer output. Some authors consider that the minimum safe infusate temperature is $32^{\circ} \mathrm{C} .{ }^{22,24,25}$ In the present study, using this limit, for both NS and PRBC, it requires infusion rates of at least $750 \mathrm{~mL} \cdot \mathrm{hr}^{-1}$ to deliver fluid at $32^{\circ} \mathrm{C}$ at $80 \mathrm{~cm}$ (i.e., the length of a standard Fenwall infusion set). These infusion rates are not often used in children, particularly in the youngest, and one can find other means in order to maintain an adequate infusate temperature. Several methods for warming iv fluids are used in children, but actually the most efficient is the coaxial heated extension tubing connected directly from the warmer to the patient. ${ }^{13,26}$ Using a Hotline ${ }^{\circledR}$, (level 1 Technologies), Presson et al. have reported that an infusate at $32^{\circ} \mathrm{C}$ could of been delivered at a flow rate as low as $100 \mathrm{~mL} \cdot \mathrm{hr}^{-1} \cdot{ }^{14}$ In another study, it was demonstrated that the two fluid warmer systems using heated extension tubing performed better than other fluids warmers with conventional tubing. ${ }^{5}$ This warming device was confirmed to be effective in clinical practice for a better preservation of body temperature in infants operated on for procedures lasting $120 \mathrm{~min}$ on average. ${ }^{26}$ Insulating the tubing beyond the heat exchangers of the conventional warmers improves their performance, but is less efficient than heated extension tubings. ${ }^{14}$

In conclusion, while fluid warmers efficiently warm infusates, the results of this study describe the rapid heat loss incurred as the infusate traverses conventional tubing en route to the patient. Thus, the clinical value of warming fluids at low flow rates while using standard infusion sets is questionable in pediatric anesthesia. Clinicians must evaluate whether the magnitude of the benefits of fluid warming in a given situation is justified by the expense, complexity and risk entailed by using the additional equipment required to accomplish this goal. These results give further arguments for using the coaxial systems in pediatric anesthesia. This system was demonstrated to be the most effective warming device independently of the rate and the type of solution to be infused. On the other hand, since cold PRBC rapidly equilibrates with ambient temperature at low flow, the usefulness of warming PRBC before infusion is questionable, especially when using a fluid warmer without a coaxial system.

Acknowledgements

The authors thank Dr. J.A.I. Schultz, and Dr. C.R. Guest for their contributions in collecting data.

\section{References}

1 Bissonnette B, Davies PJ. Thermal regulation-physiology and perioperative management in infants and children. In: Motoyama ET, Davies PJ (Eds.). Smith's Anesthesia for Infants and Children. St Louis: CV Mosby; 1995: 139-58.

2 Huckabee HCG, Craig PL, Williams JM Near drowning in frigid water: a case study of a 31-year-old 
woman. J Int Neuropsychol Soc 1996; 2: 256-60.

3 Schmidt U, Fritz K-W, Kasperczyk W, Tscherne $H$

Successful rescucitation of a child with severe hypothermia after cardiac arrest of 88 minutes. Prehospital Disaster Med 1995; 10: 60-2.

4 Sessler DI. Mild perioperative hypothermia. N Engl J Med 1997; 336: 1730-7.

5 Lenhardt R, Marker E, Goll V, et al. Mild intraoperative hypothermia prolongs postanesthetic recovery. Anesthesiology 1997; 87: 1318-23.

6 Buggy DJ, Crossley AWA. Thermoregulation, mild perioperative hypothermia and postanaesthetic shivering. Br J Anaesth 2000; 84: 615-28.

7 Bernabei AF, Levison MA, Bender JS. The effects of hypothermia and injury severity on blood loss during trauma laparotomy. J Trauma 1992; 33: 835-9.

8 Schmied H, Kurz A, Sessler DI, Kozek S, Reiter A Mild hypothermia increases blood loss and transfusion requirements during total hip arthroplasty. Lancet 1996; 347: 289-92.

9 Kurz A, Sessler DI, Lenhardt $R$ for the study of Wound Infection and Temperature Group.

Perioperative normothermia to reduce the incidence of surgical-wound infection and shorten hospitalization. Study of wound infection and temperature group. N Engl J Med 1996; 334: 1263-4.

10 Harrison MJ, Healy TEJ. A comparison of four blood warmers. Anaesthesia 1975; 30: 651-5.

11 Flancbaum L, Trooskin SZ, Pedersen H. Evaluation of blood-warming devices with the apparent thermal clearance. Ann Emerg Med 1989; 18: 355-9.

12 Faries G, Johnston C, Pruitt KM, Plouff RT. Temperature relationship to distance and flow rate of warmed iv fluids. Ann Emerg Med 1991; 20: 1198-200.

13 Schultz J-AI, Sims C, Bissonnette B. Methods for warming intravenous fluid in small volumes. Can J Anaesth 1998; 45: 1110-5.

14 Presson RG Jr, Bezruczko AP, Hillier SC, McNiece WL. Evaluation of a new fluid warmer effective at low to moderate flow rates. Anesthesiology 1993; 78: 974-80.

15 Henker R, Bernardo LM, O’Connor K, Sereika S. Evaluation of four methods of warming intravenous fluids. J Emerg Nurs 1995; 21: 385-90.

16 Norman EA, Abmad I, Zeig NJ. Delivery temperature of heated and cooled intravenous solutions. Anesth Analg 1986; 65: 693-9.

17 Kreith F, Bohn MS. Principles of Heat Transfer, 5th ed. New York: West Publishing Co., 1993.

18 Werner J. Biophysics of heat exchange between body and environment. In: Blatteis C (Ed.). Physiology and Pathophysiology of Temperature Regulation. New
Jersey: World Scientific, 1998: 25-45.

19 Dunham CM, Belzberg H, Lyles R, et al. The rapid infusion system: a superior method for the resuscitation of hypovolemic trauma patients. Resuscitation 1991; 21: 207-27.

20 Browne DA, de Boeck $R$, Morgan M. An evaluation of the Level 1 blood warmer series. Anaesthesia 1990; 45: 960-3.

21 Malcom-Thomas B, Rolly G Experimental assessment of the Fenwal blood warming system. Acta Anaesthesiol Belg 1974; 1: 100-10.

22 Presson RG Jr, Haselby KA, Bezruczko AP, Barnett E. Evaluation of a new high-efficiency blood warmer for children. Anesthesiology 1990; 73: 173-6.

23 Ubl L, Pacini D, Kruskall MS. A comparative study of blood warmer performance. Anesthesiology 1992; 77: 1022-8.

24 Russell WJ. A review of blood warmers for massive transfusion. Anaesth Intensive Care 1974; 2: 109-30.

25 Manners JM, Mills KLM. Another blood warmer. Some observations of blood changes using the "Hemokinetitherm". Anaesthesia 1968; 23: 646-56.

26 Courrèges $P$, Sorba F, Lecoutre D, Bayart $R$ Evaluation of the Hotline ${ }^{\mathrm{TM}}$ fluid warmer with children under 10 kg (French). Ann Fr Anesth Réanim 1994; 13: 904-7. 